\title{
Pay Equity for Women in Academic Libraries: An Analysis of ARL Salary Surveys, 1976/77-1983/84
}

\section{Jean Meyer Ray and Angela Battaglia Rubin}

In recent years pay equity has become an important employment issue in librarianship, as in other service fields where women predominate. Analysis of Association of Research Libraries Annual Salary Survey data from 1976/77 to 1983/84 reveals that a majority of women university librarians are still clustered at lower levels of status and pay. However, the percentage of women among all administrators has risen from 27.6 percent to 45 percent, and the proportion of all women who are in middle management now approaches one-third. With a 1983/84 sex salary differential of 13 percent, progress towards equity is nevertheless very slow.

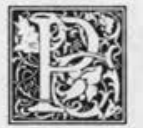

ay equity has been hailed as the employment issue of the 1980 s. To achieve this goal requires overcoming formidable barriers to equality. It pits women, awakened to their financial plight, against tradition, custom, and the entrenched power of the institutions that have profited from the general low level of women's compensation. The bottom line in equal rights is salary. To what extent has sex equality been achieved in university library pay scales?

Pay equity and its synonym, comparable worth, are both treated in this paper as abbreviated terms for the longer phrase, equal pay for work of comparable value. This concept calls for compensation to be determined by objective job evaluation techniques that analyze duties in terms of required knowledge, skill, effort, responsibility, and working conditions. It must be applied across all job families (not within just one closely related group) in a bias-free manner and without reliance on prevailing compensation levels. ${ }^{1}$ It is thus a broadening of the earlier principle of equal pay for equal work, which could be enforced only when jobs could be proven exactly or substantially equal. Pay equity operates to protect women and minority persons from being compensated by a lower pay scale than that used for white males.

\section{WOMEN'S COMPENSATION- THEN AND NOW}

Pay equity is, of course, not a new issue. It came into prominence during World War I, when women entered the labor market because of the shortage of male workers. For example, an article appearing in Economic Journal in 1922 entitled "Equal Pay to Men and Women for Equal Work," discusses the problem in Britain. ${ }^{2}$ 
It contains two basic, but now archaic, assumptions: (1) all working men are married, with families to support, but all working women are single, with no dependents; and (2) women are inevitably less productive and are less useful in emergencies. Sixty years ago, with these convictions, even a liberal thinker could not come out more than slightly in favor of equal pay for women.

Although there were efforts to achieve equal pay for women through the $\mathrm{Na}$ tional War Labor Board and during the era of Rosie the Riveter in World War II, the old problem of differing pay scales for men and women surfaced in the United States as something remediable with the Equal Pay Act of 1963. This law required that an employer must provide the same compensation to both sexes for positions that are substantially similar with regard to skill, effort, responsibility, and working conditions, unless the pay differential is based on a factor other than sex. Other actions have followed: Title VII of the Civil Rights Act of 1964 again forbade discrimination in employment, as did two presidential executive orders (11246 and 11478), the 1978 Civil Service Reform Act, and several court decisions (notably County of Washington, Oregon, $v$. Gunther). ${ }^{3}$ Yet, twenty years after the Equal Pay Act, the average woman who works full time year-round is paid only 59 cents for every dollar earned by a male worker. How can this be?

Great strides have been made in achieving equal pay for equal work, and in achieving an acceptance of this principle as fair. However, the major cause for the continuing wage gap between the pay of men and women is the concentration of women workers in a few low-paying occupations that are sex-segregated and where positions are dead-end. Approximately 80 percent of working females are in clerical, sales, service, and factory jobs. ${ }^{4}$ Of the remaining 20 percent who are professional and technical workers, a large share are found in lower-paid, female-dominated service ("helping") fields of nursing, school teaching, social work, and of course, librarianship. Even within these professions, moreover, although almost all salaries are low compared to those in male-dominated fields, there is frequently further sex segregation in that the female majority remains in lower-paying positions, while men tend to rise to the top.

Major forces in opposition to pay equity are firms that employ many women in low-paid slots. It would not be expedient nor even permissible to lower men's pay, so employers fear the cost of raising women's pay, as would be necessary to achieve an across-the-board application of comparable worth. ${ }^{6}$ In times of economic stress this is a particularly strong argument. However, a voluntary plan to inaugurate pay equity after appropriate job evaluation might be less expensive than years of back pay awarded as a result of litigation.

\section{FEMINIZATION OF LIBRARIANSHIP}

As in most professional fields, librarians of a century ago were mostly male. However, according to the 1870 U.S. Census, 20 percent of the 213 librarians polled were female. ${ }^{7}$ The next two censuses lumped librarians with authors and other literary persons, but by 1900 , when they were again a separate category, the number of librarians had become twenty times greater $(4,184)$, and women constituted 75 percent of those listed!

It was during this period that Melvil Dewey launched his library school at Columbia University. The program attracted mostly female students and was therefore rejected by the board of trustees (although the president approved). Dewey took the school with him when he moved to Albany. ${ }^{8}$

The feminization of librarianship proceeded apace. Important causative factors were limited budgets for hiring staff and the paucity of other vocations for educated women. Working in the genteel atmosphere of the library was a respectable occupation for the young woman college graduate, but she was too "ladylike" and had too few other options to demand more than a pittance as compensation for this exposure to culture and the opportunity to be of service. The 1930 census recorded 29,613 librarians, with women's participation climbing to a peak of 91 percent. From there it slowly receded to 82 
percent by 1970 , but has risen again slightly, to 83 percent in 1980 .'

This drop in the female proportion coincides, of course, with the increased entrance of men into the profession, beginning slowly about the time of World War II and mounting faster in the 1950s and 1960 s. It was hoped that this trend would improve the status of librarianship and raise depressed salaries. However, there is little evidence that it has assisted the disadvantaged female majority, because men were hired for most high-level positions and the salary gap between the sexes has widened.

It is now clear that the increased entrance of men has actually reinforced and expanded a dual career pattern in librarianship according to gender. Academic librarianship has the highest percentage of men and is the most prestigious. Library work with children, and in primary and secondary schools, attracts few men and is less valued. ${ }^{10}$ Moreover, men in whatever field are expected to climb quickly to administrative roles and high salaries - and a substantial number of them do. The selffulfilling prophecy for women is that they will be content with subsidiary roles and low salaries, and any upward mobility for them will usually be painfully slow and reach only middle management.

Two outstanding women have conducted extensive research on the status of women librarians. Anita Schiller's pioneering study, Characteristics of Professional Personnel in College and University Libraries (1969) was the first published report on comparative attributes, status, and compensation of male and female academic librarians. ${ }^{11}$ This work showed irrefutably that the wide gap between average salaries of men and women, which increased with added experience, could not be entirely explained by greater educational attainments, more research and publication, more professional activity, or greater mobility on the part of men but included a strong component of sex discrimination.

This has been followed by other important contributions on the issue of the disadvantaged majority. ${ }^{12}$ Kathleen Heim has been the author or editor of equally significant works issued recently. Espe- cially noteworthy is her part in the comprehensive study on women librarians' roles, sponsored by the American Library Association Committee on the Status of Women in Librarianship, that resulted in Career Profiles and Sex Discrimination in the Library Profession. ${ }^{13}$

\section{SALARY POLICY}

Following decades in which there was a general reluctance to face the twin issues of sex equality in the library and a widely disparate pay scale, the American Library Association began to address some aspects of the pay equity problem in the 1970 s. ${ }^{14}$ After years of committee activity, the February 1979 issue of American Libraries, in a summary of activities at the Midwinter Meeting, reported that ALA Council

Adopted as ALA policy an OLPR (Office for Library Personnel Resources) statement on comparable rewards. . . . ALA supports salary administration which gives reasonable and comparable recognition to positions having administrative, technical, subject, and linguistic requirements. Whenever possible there should be as many at the top rank with less than 30 percent administrative load as there are at the highest rank carrying over 70 percent administrative load. ${ }^{15}$

Although some of the wording is ambiguous, this statement appears to be a call from a high policy-making body for the application of pay equity within individual libraries. Was it heeded? The absence of response in the library press suggests that it was not even heard in the furor of the debate over maintaining the ERA boycott of Chicago.

Nevertheless, in academic libraries personnel administration has usually attempted to steer a middle course between the industrial model of a rigid hierarchy of positions and the academic model of recognizing individual merit. To what extent is the professional librarian to be rewarded for excellence in the performance of the daily requirements of the position description, and how much consideration should be given to professional development and merit? Especially where librarians have achieved faculty status, it becomes necessary to reduce the emphasis 
on administrative responsibilities and to examine scholarship, research, and publication in making promotion and tenure decisions as well as in recommendations for salary increases.

An examination of the salary policies of ten representative libraries in the ARL, as detailed in a 1981 report, reveals great diversity in systems and procedures but little specific recognition of the need to improve financial rewards for the deserving nonadministrators beyond those small amounts normally accruing from longevity and acceptable performance. ${ }^{16}$ An earlier ARL study of classification schemes revised in 1978 includes material from four university libraries (Cornell, Duke, Stanford, and Yale). The study indicates clearly that promotion in status and salary may result not only from advancement in administration but equally through excellence in performance, scholarship, and professional achievement. ${ }^{17}$

Probably the best-known effort to improve the role of academic librarians is the two-track matrix structure of position categories and professional ranks inaugurated at Columbia University a decade ago. ${ }^{18}$ Each librarian holds not only a position, e.g., cataloger, bibliographer, or reference librarian, whose level is determined by administrative responsibility, but also a rank as Librarian I-IV based on peer evaluation of individual development and contribution to the profession. This plan provides a means to raise status even when no upward mobility positionwise is possible, but there is only brief allusion to financial rewards.

\section{STUDIES OF ACADEMIC LIBRARIANS' SALARIES}

Between 1970 and 1974 the Council on Library Resources demonstrated its concern with librarians' compensation by the publication of a series of three reports on salaries of academic librarians as compared with the teaching faculty. ${ }^{19}$ It is clear that there is a

pronounced pyramidal structure in academic libraries, with a handful of more or less well-paid librarians at the top and a wide base of very low-paid positions at the bottom. Academic librarianship has seemed to be a profession in which there are too few well-paying positions to attract and retain highly competent young people in sufficient number. ${ }^{20}$

Unfortunately, the data were not analyzed by sex. The only allusion to a sex problem is a statement in the $1969-70$ report that the predominance of women in the profession has "facilitated retention of salary structures which would be unacceptable to a largely male profession. ${ }^{\prime 21}$ The 1972-73 report concludes that:

Fewer than 10 percent of the professional librarians are in positions in which the average compensation exceeds that of assistant professor in similar institutions. ${ }^{22}$

In $1975 / 76$, after a hiatus of three years, the CLR and the Association of College and Research Libraries conducted a joint survey. ${ }^{23}$ Coverage was expanded to include two-year colleges, and breakdowns by sex and race were incorporated at last. Of 13,057 librarians surveyed, 61.5 percent were female; women constituted a majority at almost every level (except administrative positions) and earned less in every capacity, from 3 percent less for entering librarians to 23 percent less for directors. ${ }^{24}$ One table compares librarians with the four ranks of teaching faculty in three types of institutions. The conclusion is inescapable. Average salaries for librarians in the nondirector levels are equivalent to the average for assistant professor and never as high as the average for associate professor. $^{25}$

In addition, the Special Libraries Association has been conducting salary surveys at three-year intervals since $1967 .{ }^{26}$ Data compiled in 1979, for example, show median salaries for academic librarians among the lowest when members are grouped by type of institution. Women earn less than men at every salary level. This occurs even when the number of persons supervised and the years of experience are equal. ${ }^{27}$

The most important series of data on internal pay equity in university libraries began to appear in 1976/77 when the ARL expanded its Annual Salary Survey to include breakdowns by sex and position similar to those in the ACRL study previously discussed. ${ }^{28}$ Eight years of statistics are now 
available as a source for average salaries paid to librarians in 90 large university libraries in $1976 / 77$. This was enlarged to 105 by $1984 / 85$. Although the survey also gives information on (1) nonuniversity ARL member libraries; (2) minority librarians; (3) entry-level salaries; (4) relations between median salaries and the Consumer Price Index; and (5) regional variations in salaries, this paper will be concerned only with issues related to the gender gap. It will focus mostly on changes between two extreme years, $1976 / 77$ and $1983 / 84$, with occasional mention of the intervening years.

Each Annual Salary Survey from 1976/77 to $1982 / 83$ contains a table entitled "Number and Average Salaries of ARL Librarians." It divides librarians into nineteen categories: director, associate director, assistant director, medical/law head, branch head, subject specialist, functional specialist (involved with media, personnel management, fiscal matters, or automation and systems), eight types of department heads, and "other." "Other" is divided by years of experience into over 15 , $10-15,5-10$, and under 5. Beginning in $1983 / 84$, "other" has been split into reference, catalog, and a further other. All are divided by years of experience.

In $1984 / 85$, data for law and medical librarians were moved into separate tables. Figures for these librarians are incomplete. This change in the target population has made exact comparisons with earlier years impossible; thus, figures for 1984/85 generally will be omitted.

There are some omissions from the published tabulations. A few universities did not supply detailed salary data in the early years. Moreover, some universities did not include salaries of directors in their salary rosters, and between 1976/77 and $1983 / 84$ the number of directors appeared to be from 5 to 19 fewer than the number of institutions tabulated. However, after a special appeal, more figures were made available, and the number of directors whose salaries were included rose from 81 in $1982 / 83$ to 95 in $1983 / 84$.

Furthermore in some large systems there may be someone, such as a dean, at a higher level who has the ultimate library authority, is probably male, and is omitted from the survey. These factors indicate that the real average salary for male librarians is higher than ARL statistics reveal. Finally, the ARL surveys make no attempt to compare librarians' salaries with those of the teaching faculty.

What significant trends can be derived from the ARL data? First, the proportion of women was 61.6 percent in 1976/77, fell to 61.4 percent in $1978 / 79$, and grew to 63.9 percent by $1983 / 84$. Women's average salaries were lower than men's every year in almost every category. Overall they gained only 2.5 percentage points during the seven-year period. Figure 1 shows that the difference between average salaries paid to men and women dropped from 15.5 percent in $1976 / 77$ to 13 percent in $1983 / 84$. Incidentally, these percentages are fairly close-though moving in the opposite direction-to those issued by the Women's Equity Action League for salaries of women faculty members compared to those of men, i.e., a 15 percent disparity in 1982 widened to 19 percent in $1983 / 84$. $^{29}$

One may also compare the distribution patterns by sex when the nineteen categories listed are grouped with changes noted through seven years. What is apparent in figure 2 is that the proportions of male and female librarians who are middle managers (branch and department heads) are almost the same each year ( 24.5 and 25.1 percent in 1976/77, increasing to 31.5 and 29.5 percent in $1983 / 84$ ). But other percentages are quite different for each sex.

The proportion of women in high administrative roles is up (from 3.7 to 5.6 percent), and the proportion of men goes down from 15.5 to 12.2 percent. Specialists, both subject and functional, comprise 21.3 percent of men in $1976 / 77$. This is down to 19.4 percent in $1983 / 84$. The number of specialists who are female rose from 12.1 percent in $1976 / 77$ to 14.9 percent in $1982 / 83$, but dropped to 13.6 percent in $1983 / 84$. Especially significant is the 59.1 percent of women who are in nonadministrative positions in $1976 / 77$, as opposed to 38.7 percent of men. Both these percentages have grown smaller by $1983 / 84$, down to 51.3 percent for women and 36.9 for men, largely, it may be presumed, be- 

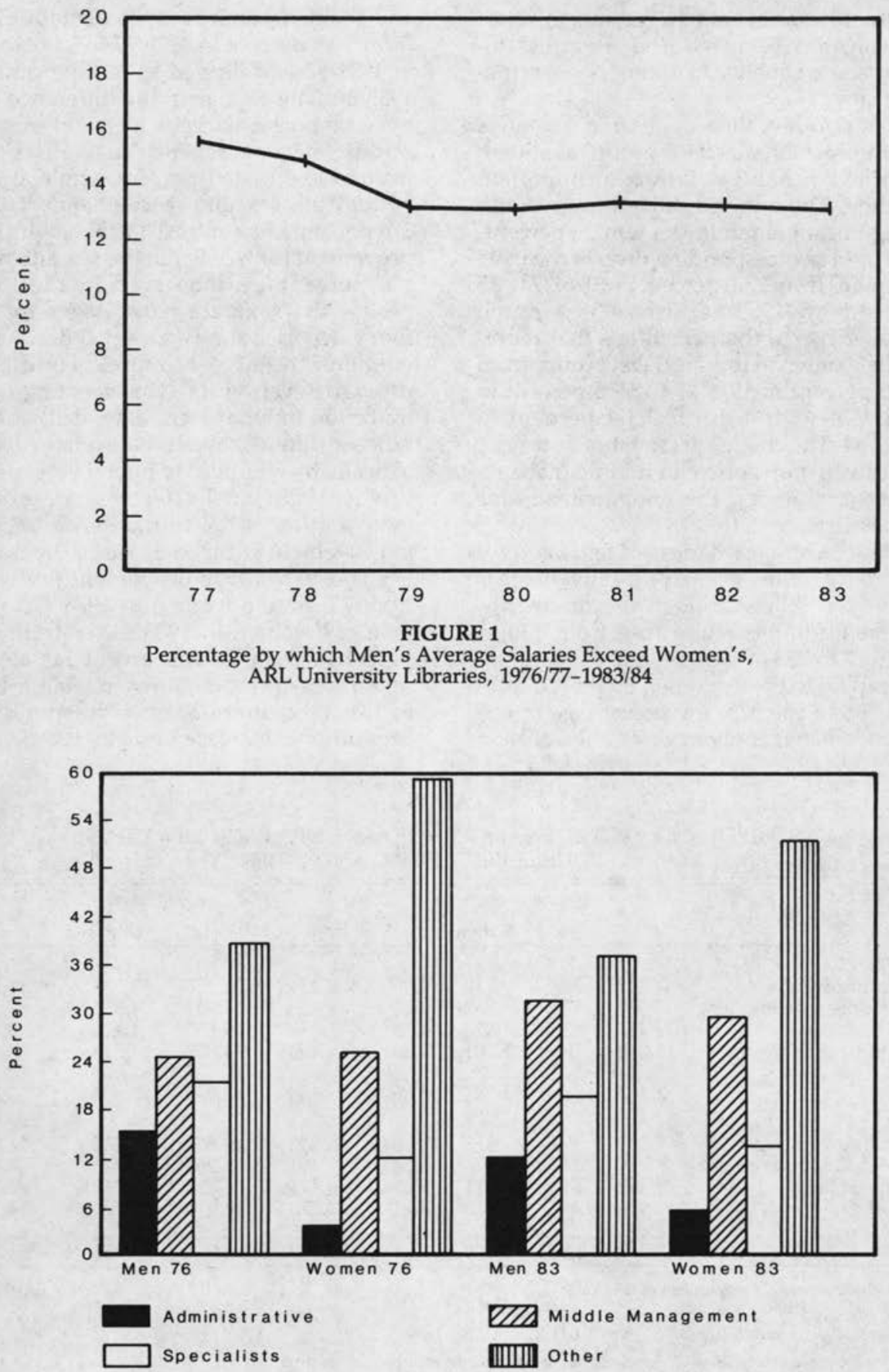

FIGURE 2

Percentage of University Librarians by Sex and Rank Level, $1976 / 77$ and $1983 / 84$ 
cause the number of new recruits to librarianship has been reduced. Progress towards sex equality in status is nevertheless slow.

It is also revealing to observe sex ratios within each broad status group, as shown in table 1; in only two is there an important change. The administrative group shows a significant climb in the female percentage (and a corresponding drop in the male element) from 27.6 percent in $1976 / 77$ to 45 percent in $1983 / 84$. There is a much smaller rise in the percentage that represents women in the specialist group, from 47.8 percent in $1976 / 77$ to 55.5 percent in $1982 / 83$, with a dip to 55.4 percent in $1983 / 84$. The change in sex ratio, however, is scarcely perceptible in middle management and among the nonadministrative generalists.

When average salaries are tabulated for the four groups, women's disadvantage is plainly visible. Although the number of women administrators rose from 130 in $1976 / 77$ to 253 in 1983/84, and average salaries paid to these women increased from $\$ 24,988$ to $\$ 39,875$, the percentage of difference between average salaries of men and women administrators actually rose from 11.5 percent in $1976 / 77$ to 15 percent in $1981 / 82$ and dipped to 14.3 percent in $1983 / 84$. The change in the difference between average salaries of men and women middle managers and specialists remained less than 1 percent, while at the bottom the sex difference changed only 1.3 percent. In contrast to the slight improvement for women in the sex differential percentages observed in the total group, the separate percentages for all four categories showed a small decline in women's relative economic condition through seven years. This seeming contradiction in what were essentially insignificant differences can be explained statistically by reference to interaction effect.

When individual categories are examined starting at the top, an encouraging improvement is the increase in the number and percentage of women directors, from 73 men, 8 women in $1976 / 77$ to 76 men, 19 women in 1983/84, or from 9.9 percent female to 20 percent female in seven years. This is shown in table 2 . Unfortunately, there is no corresponding proportional increase in salary level.

TABLE 1

NUMBER AND AVERAGE SALARIES OF ARL UNIVERSITY LIBRARIANS AT FOUR LEVELS, 1976/77 AND 1983/84

\begin{tabular}{|c|c|c|c|c|c|c|c|c|}
\hline \multirow[b]{2}{*}{ Rank Level } & \multicolumn{4}{|c|}{ Number of Staff } & \multicolumn{4}{|c|}{ Average Salaries } \\
\hline & Men & $\%$ & Women & $\%$ & Men & Women & Difference & Difference \\
\hline $\begin{array}{l}1976 / 77^{\star} \\
\text { Administrative } \\
\text { Middle management } \\
\text { Specialist } \\
\text { Other }\end{array}$ & $\begin{array}{l}341 \\
537 \\
467 \\
848\end{array}$ & $\begin{array}{l}72.4 \\
37.8 \\
52.2 \\
29.0\end{array}$ & $\begin{array}{r}130 \\
883 \\
427 \\
2,081\end{array}$ & $\begin{array}{l}27.6 \\
62.2 \\
47.8 \\
71.0\end{array}$ & $\begin{array}{r}\$ 28,224 \\
18,268 \\
17,318 \\
14,450\end{array}$ & $\begin{array}{r}\$ 24,988 \\
16,932 \\
15,897 \\
13,937\end{array}$ & $\begin{array}{r}\$ 3,236 \\
1,336 \\
1,421 \\
513\end{array}$ & $\begin{array}{r}11.5 \\
7.3 \\
8.2 \\
3.6\end{array}$ \\
\hline Total & $\overline{2,193}$ & $\overline{38.4}$ & $\overline{3,521}$ & $\overline{61.6}$ & $\overline{18,138}$ & $\overline{15,334}$ & $\overline{2,804}$ & $\overline{15.5}$ \\
\hline $\begin{array}{l}1983 / 84+ \\
\text { Administrative } \\
\text { Middle management } \\
\text { Specialist } \\
\text { Other }\end{array}$ & $\begin{array}{l}309 \\
799 \\
492 \\
939\end{array}$ & $\begin{array}{l}55.0 \\
37.6 \\
44.6 \\
28.9\end{array}$ & $\begin{array}{r}253 \\
1,326 \\
611 \\
2,310\end{array}$ & $\begin{array}{l}45.0 \\
62.4 \\
55.4 \\
71.1\end{array}$ & $\begin{array}{l}46,530 \\
29,491 \\
26,471 \\
23,723\end{array}$ & $\begin{array}{l}39,875 \\
27,263 \\
24,222 \\
22,254\end{array}$ & $\begin{array}{l}6,655 \\
2,228 \\
2,249 \\
1,136\end{array}$ & $\begin{array}{r}14.3 \\
7.6 \\
8.5 \\
4.9\end{array}$ \\
\hline Total & $\overline{2,539}$ & $\overline{36.1}$ & $\overline{4,500}$ & $\overline{63.9}$ & $\overline{28,723}$ & $\overline{24,988}$ & $\overline{3,735}$ & $\overline{13.0}$ \\
\hline
\end{tabular}

"Excludes Chicago, Harvard, Illinois, and Yale tExcludes Chicago

Based on ARL Annual Salary Survey, 1976/77, table 1, p.31; 1983, table 13, p.26

Administrative includes: director, associate director, assistant director, medical/law head

Middle Management includes: branch head, department head (reference, cataloging, acquisition, serials, document/maps, circulation, special collections, other)

Specialist includes: subject, functional

Other includes: all other nonadministrative positions 
TABLE 2

NUMBER AND AVERAGE SALARIES OF ADMINISTRATORS IN ARL UNIVERSITY LIBRARIES, 1976/77 AND 1983/84

\begin{tabular}{|c|c|c|c|c|c|c|c|c|}
\hline \multirow[b]{2}{*}{ Position } & \multicolumn{4}{|c|}{ Number of Staff } & \multicolumn{4}{|c|}{ Average Salary } \\
\hline & Men & $\%$ & Women & $\%$ & Men & Women & Difference & Difference \\
\hline \multicolumn{9}{|l|}{$1976 / 77^{*}$} \\
\hline Director & 73 & 90.1 & 8 & 9.9 & $\$ 36,191$ & $\$ 34,275$ & $\$ 1,916$ & 5.3 \\
\hline Associate director & 71 & 75.5 & 23 & 24.5 & 28,192 & 27,263 & 929 & 3.3 \\
\hline Assistant director & 144 & 68.2 & 67 & 31.8 & 23,978 & 22,313 & 1,665 & 6.9 \\
\hline Medical/law head & 53 & 62.4 & 32 & 37.6 & 28,828 & 26,630 & 2,198 & 7.6 \\
\hline \multicolumn{9}{|l|}{$1983 / 84 t$} \\
\hline Director & 76 & 80.0 & 19 & 20.0 & 59,701 & 56,953 & 2,748 & 4.6 \\
\hline Associate director & 60 & 45.5 & 72 & 54.5 & 43,146 & 39,774 & 3,372 & 7.8 \\
\hline Assistant director & 121 & 50.8 & 117 & 49.2 & 38,119 & 36,229 & 1,890 & 5.0 \\
\hline Medical/law head & 52 & 53.6 & 45 & 46.4 & 50,757 & 42,303 & 8,459 & 16.7 \\
\hline
\end{tabular}

•Excludes Chicago, Harvard, Illinois, and Yale

tExcludes Chicago

Based on ARL Annual Salary Survey. 1976/77, table 1, p.31; 1983, table 13, p.26

The difference between the pay of women and men directors actually rose slightly from 5.3 percent in $1976 / 77$ to 6.4 percent in $1982 / 83$, but fell to 4.6 percent in 1983/84. There have also been substantial gains in the number and percentage of women moving into associate and assistant director positions. In 1983/84, the number of women associate directors even exceeded the number of men by 12 (or 8 percent), and the figures were 121 men, 117 women at the assistant director level. For salaries, however, percentages through the years hover at about 8 percent lower for female associate directors and 5 percent lower for female assistant directors.

Another prestigious function is being head of a law or medical library. Compensation for heads of law and medical libraries is in fact higher on the average than for associate directors of general university libraries. Ratios here have changed from 53 men and 32 women in 1976/77 (62.4 percent male, 37.6 percent female) to 52 men and 45 women in 1983/84 (53.6 percent male, 46.4 percent female). At the same time, average salaries for women have been substantially lower than those for men, and the gap has widened from 7.6 percent in $1976 / 77$ to 16.7 percent in $1983 / 84$. Heads of special collections are also predominantly male, but the percentage of women is rising here too, from 36.1 in $1976 / 77$, changing to 34.3 percent in
$1977 / 78$, and up to 40 percent in $1983 / 84$ (See table 3). The gender gap in salaries is larger in this category than in any other, moving erratically from $\mathbf{2 0 . 2}$ percent in $1976 / 77$ to a low of 12 percent in 1977/78, then to a high of 20.5 percent in 1981/82, and ending with a 17.6 percent differential in 1983/84. It appears that where the heads of special collections are female, their average salaries are comparable to those of other department heads; if they are male their average salaries are higher than those of other department heads and may approach those of female assistant directors.

What of pay equity in middle management in general, i.e., compensation offered to heads of branches (except medi$\mathrm{cal} / \mathrm{law}$ ) and departments (other than special collections)? Here, as shown in table 3 , women hold substantial majorities, with the highest in cataloging and serials. In at least one category each year women have a slightly higher average salary than men. This is true for heads of serials five years out of seven, for circulation and documents/maps four times, and for cataloging twice. In all other categories men's average salaries are from 3.6 to 10.8 percent higher than women's in 1976/77 and from less than 1 percent to 9.4 percent higher in 1983/84, with sex differential for branch librarians highest each year.

The compilers of the ARL statistics, pursuing an issue first raised by the CLR studies, also have investigated the possibility 
TABLE 3

NUMBER AND AVERAGE SALARIES OF MIDDLE MANAGEMENT LIBRARIANS IN ARL UNIVERSITY LIBRARIES, $1976 / 77$ and 1983/84

\begin{tabular}{|c|c|c|c|c|c|c|c|c|}
\hline \multirow[b]{2}{*}{ Position } & \multicolumn{4}{|c|}{ Number of Staff } & \multicolumn{4}{|c|}{ Average Salary } \\
\hline & Men & $\%$ & Women & $\%$ & Men & Women & Difference & Difference \\
\hline $\begin{array}{l}1976 / 77^{\star} \\
\text { Branch Head } \\
\text { Department Head: }\end{array}$ & 194 & 38.8 & 306 & 61.2 & $\$ 18,924$ & $\$ 16,884$ & $\$ 2,040$ & 10.8 \\
\hline $\begin{array}{l}\text { Reference } \\
\text { Cataloging } \\
\text { Acquisition } \\
\text { Serials } \\
\text { Doc./Maps } \\
\text { Circulation } \\
\text { Spec. collection } \\
\text { Other }\end{array}$ & $\begin{array}{l}36 \\
24 \\
43 \\
20 \\
31 \\
37 \\
62 \\
90\end{array}$ & $\begin{array}{l}28.8 \\
20.0 \\
44.8 \\
26.0 \\
40.8 \\
44.6 \\
63.9 \\
36.6\end{array}$ & $\begin{array}{r}89 \\
96 \\
53 \\
57 \\
45 \\
46 \\
35 \\
156\end{array}$ & $\begin{array}{l}71.2 \\
80.0 \\
55.2 \\
74.0 \\
59.2 \\
55.4 \\
36.1 \\
63.4\end{array}$ & $\begin{array}{l}18,222 \\
18,983 \\
18,546 \\
16,331 \\
15,526 \\
15,466 \\
20,233 \\
17,725\end{array}$ & $\begin{array}{l}17,558 \\
18,208 \\
16,972 \\
16,734 \\
16,576 \\
16,811 \\
16,151 \\
16,258\end{array}$ & $\begin{array}{c}664 \\
775 \\
1,574 \\
403+ \\
1,050 \dagger \\
1,345+ \\
4,082 \\
1,467\end{array}$ & $\begin{array}{r}3.6 \\
4.1 \\
8.5 \\
2.4 \\
6.3 \\
8.0 \\
20.2 \\
8.3\end{array}$ \\
\hline $\begin{array}{l}1983 / 84 \ddagger \\
\text { Branch Head } \\
\text { Department Head: }\end{array}$ & 217 & 37.3 & 365 & 62.7 & $\$ 30,357$ & $\$ 27,496$ & $\$ 2,861$ & 9.4 \\
\hline $\begin{array}{l}\text { Reference } \\
\text { Cataloging } \\
\text { Acquisition } \\
\text { Serials } \\
\text { Doc./Maps } \\
\text { Circulation } \\
\text { Spec. collection } \\
\text { Other }\end{array}$ & $\begin{array}{r}50 \\
40 \\
39 \\
17 \\
42 \\
46 \\
60 \\
288\end{array}$ & $\begin{array}{l}32.5 \\
25.6 \\
35.1 \\
21.8 \\
36.2 \\
45.5 \\
60.0 \\
39.6\end{array}$ & $\begin{array}{r}104 \\
116 \\
72 \\
61 \\
74 \\
55 \\
40 \\
439\end{array}$ & $\begin{array}{l}67.5 \\
74.4 \\
64.9 \\
78.2 \\
63.8 \\
54.5 \\
40.0 \\
60.4\end{array}$ & $\begin{array}{l}29,134 \\
30,121 \\
29,303 \\
26,358 \\
26,690 \\
25,404 \\
32,840 \\
29,387\end{array}$ & $\begin{array}{l}28,806 \\
28,900 \\
27,107 \\
26,783 \\
26,597 \\
24,852 \\
27,060 \\
26,797\end{array}$ & $\begin{array}{c}328 \\
1,221 \\
2,196 \\
425+ \\
93 \\
552 \\
5,780 \\
2,590\end{array}$ & $\begin{array}{l}1.1 \\
4.0 \\
7.5 \\
1.6 \\
.003 \\
2.2 \\
17.6 \\
8.8\end{array}$ \\
\hline
\end{tabular}

•Excludes Chicago, Harvard, Illinois, and Yale tWomen's salaries higher †Excludes Chicago

Based on ARL Annual Salary Survey, 1976/77, table 1, p.31; 1983, table 13, p.26

that specialists, either subject or functional, might be better paid than the ordinary nonadministrative librarian. ${ }^{30}$ There is no evidence that this has happened, as table 4 demonstrates. The number of subject specialists grew rapidly from 634 in $1976 / 77$ to 981 in $1981 / 82$, but dropped to 720 in 1983/84. This group was 57.6 percent female in 1982/83 but 55.4 percent female in 1983/84. Meanwhile, the salaries of men subject specialists exceeded those of women by 7.1 percent in 1976/77, by only 3.6 percent in $1979 / 80$, but by 7.9 in 1983/84. Functional specialists, a smaller group, were also 55.4 percent female in 1983/84. Average salaries, usually higher than those for subject specialists, have varied by sex differential from 9.5 percent for men in 1976/77 down to 8.3 percent in $1982 / 83$ and then up to 9.7 percent in $1983 / 84$. Moreover, the salaries of both varieties of specialists have been somewhat lower on the whole than those paid to branch and department heads. With average salaries in $1983 / 84$ of $\$ 26,471$ for men and $\$ 24,222$ for women, one must conclude that the specialist route is not a promising avenue to high-level remuneration in the library!

At the bottom of the pyramidal structure are the generalists-the nonadministrators and the nonspecialists. The proportion of librarians at this level has decreased in seven years to 37 percent men and 51.3 percent women, but 3,249 out of a total of 7,039 librarians were still clustered there in 1983/84.

One particularly significant factor is the shift in recent years between newcomers and old timers. The number of librarians with less than ten years' experience shrank from 2,000 in 1976/77 to 1,584 in $1983 / 84$, a drop of 20.8 percent, while those with more than ten years' experience-but who were not in an administrative or specialist role-grew from 929 to 1,665 , an increase of 79.2 percent. Economic conditions throughout the nation may have restricted job mobility, thereby reducing the number of job 
TABLE 4

NUMBER AND AVERAGE SALARIES OF SPECIALSTS IN ARL UNIVERSITY LIBRARIES, 1976/77 and 1983/84

\begin{tabular}{lccrrrrrr}
\hline \hline & \multicolumn{9}{c}{ Number of Staff } & \multicolumn{4}{c}{ Average Salary } \\
Position & Men & $\%$ & Women & $\%$ & Men & Women & Difference & \% of \\
Difference
\end{tabular}

*Excludes Chicago, Harvard, Illinois, and Yale tExcludes Chicago

Based on ARL Annual Salary Survey, 1976/77, table 1, p.31; 1983, table 13, p.26

changes. Another consideration is that fewer young women are leaving the profession after becoming mothers. Many are continuing after a brief maternity leave.

How are the salaries of the "other" group at the bottom of the pyramid? The categories of "under five years" and "five to ten years" (in table 5) show the closest equity between the sexes, with a 3.6 percent differential for men in 1976/77, down to 2.7 percent in $1982 / 83$, but back up to 3.8 percent in 1983/84. Salaries for those with more than fifteen years' experience are slightly below the average for middle management. They exceed the salaries received by some department heads. Furthermore, the 621 women nonadministrators with more than fifteen years' experience constituted the largest single category of women librarians in 1982/83.
They earned an average salary of $\$ 24,972$. This is more than the salary of female specialists or heads of circulation departments. By 1983/84 the total of women nonadministrators with more than fifteen years' experience had increased to 701 , with an average salary of $\$ 25,944$. This is still less than half the average salary of the nineteen women directors who succeeded in reaching the top of the pyramid.

The 1983/84 ARL Salary Survey includes a new table presenting number and average salaries of men and women in ten fouryear groups according to total library experience. ${ }^{13}$ Librarians have long careers. Twenty percent have more than twenty years of service. The female proportion falls from 71.7 percent with $0-3$ years' service, to 64.7 percent for $4-19$ years, and to 55 percent for $20-35$ years. There are 101

TABLE 5

NUMBER AND AVERAGE SALARIES OF "OTHER" (NONADMINISTRATIVE) LIBRARIANS IN ARL UNIVERSITY LIBRARIES, 1976/77 AND 1983/84

\begin{tabular}{|c|c|c|c|c|c|c|c|c|}
\hline \multirow[b]{2}{*}{$\begin{array}{l}\text { Years of } \\
\text { Experience }\end{array}$} & \multicolumn{4}{|c|}{ Number of Staff } & \multicolumn{4}{|c|}{ Average Salary } \\
\hline & Men & $\%$ & Women & $\%$ & Men & Women & Difference & Difference \\
\hline \multicolumn{9}{|l|}{$1976 / 77^{*}$} \\
\hline Over 15 years & 125 & 27.4 & 331 & 72.6 & $\$ 17,662$ & $\$ 16,513$ & $\$ 1,149$ & 6.5 \\
\hline $10-15$ years & 136 & 28.8 & 337 & 71.2 & 15,920 & 15,571 & 349 & 2.2 \\
\hline $5-10$ years & 266 & 29.8 & 628 & 70.2 & 14,497 & 14,064 & 433 & 3.0 \\
\hline Under 5 years & 321 & 29.0 & 785 & 71.0 & 12,538 & 12,048 & 490 & 3.9 \\
\hline \multicolumn{9}{|l|}{$1983 / 84 t$} \\
\hline Over 15 years & 300 & 30.0 & 701 & 70.0 & $\$ 27,635$ & $\$ 25,944$ & $\$ 1,691$ & 6.1 \\
\hline $10-15$ years & 188 & 28.4 & 475 & 71.6 & 24,342 & 23,660 & 682 & 2.8 \\
\hline $5-10$ years & 250 & 30.8 & 563 & 69.2 & 21,885 & 20,995 & 890 & 4.1 \\
\hline Under 5 years & 201 & 26.1 & 570 & 73.9 & 18,037 & 17,828 & 209 & 1.2 \\
\hline
\end{tabular}

"Excludes Chicago, Harvard, Illinois, and Yale tExcludes Chicago

Based on ARL Annual Salary Survey, 1976/77, table 1, p.31; 1983, table 13, p.26 
persons with more than 35 years ( 22 male, 79 female).

The salary lines for men and women rise steeply during the first twenty years. After fifteen to twenty years the female line is almost flat and the disparity between salaries increases dramatically (see figure 3 ). Thus the differential for males rises from 2.8 percent for those in the $0-3$ category to an appalling 30 percent after more than thirty-five years (male average $\$ 45,155$, female $\$ 31,620$ ). This salary figure is somewhat suspect, along with the averages paid to all female categories over twenty years (ranging from $\$ 29,420$ to $\$ 31,021)$, because they seem too high compared with the average salary $(\$ 27,263)$ paid in 1983/84 to female branch and department heads.

\section{WOMEN'S SITUATION TODAY}

It is the almost forgotten generation of older women librarians who are affected most from past sex and present age discrimination. They entered librarianship when even the best-qualified female had almost no opportunity to climb to upper administrative levels. There was little en- couragement for them to attain a doctorate, conduct research, seek an elected office in professional organizations, or strive for promotion to middle management. They had no mentors grooming them for success, except perhaps as department heads where the proven route was by impeccable on-the-job performance.

More recently, management training programs have been aimed at the young and promising, not at those nearing retirement. Moreover, many who married and had children were confronted by pressure to make a career or family decision. Because of personal choice or yielding to existing prejudices, many left temporarily or compromised by working part-time. This practice was often cited as proof of a lack of professional zeal and aspiration. Upon reentry they were much less likely to achieve middle management status or to receive more than meager remuneration. A few outstanding women have moved up to the role of director or acting director at the end of their careers, but the average age of all women administrators in 1980 was forty-six. ${ }^{32}$ It is the young, welleducated, highly mobile women, with

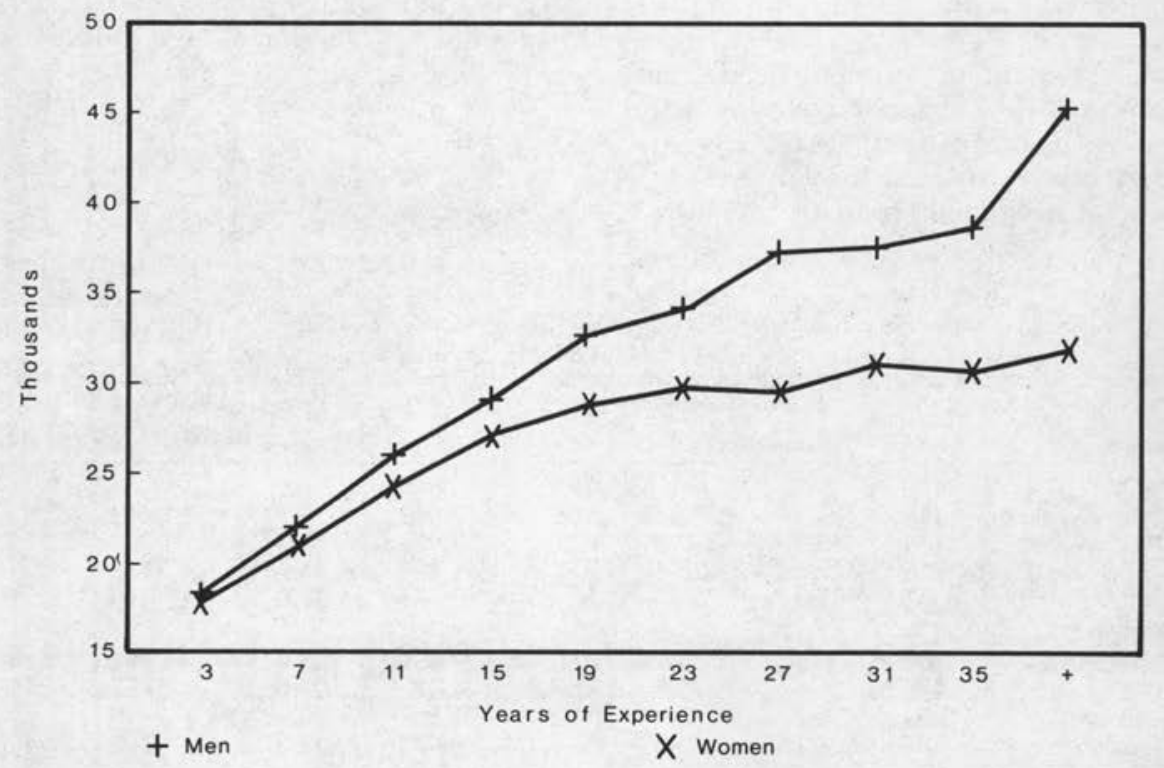

FIGURE 3

Average Salaries of ARL University Librarians by Sex and Years of Experience, 1983/84 
new skills, attitudes, and expectations who are chief beneficiaries of the current concern with sex equality.

Recent studies have examined the extent to which the status of women librarians has been affected by factors such as lower educational attainments, less experience, limited mobility, more career interruptions, less involvement with professional associations, or fewer publications. Results are incomplete and not always consistent and comparable. They do indicate the importance of these factors and the myth that they account for all the differences. Clearly gender still plays a critical part in career patterns. The need for more research and for remedial action remains.

What gains have women made? Not many. Organized efforts by librarians at Stanford, University of California-Berkeley, Temple and University of Minnesota have recently led to increases in women's salaries. ${ }^{33}$ In contrast there is the attempt by the Office of Personnel Management to lower the standards for federal librarians and the uncertainty caused by the Merwine case as to whether the master's degree is a valid minimum requirement. ${ }^{34}$ Any lowering of the entry-level standards could have a disastrous impact upon the profession.

\section{THE FUTURE}

There are some hopeful trends within the profession. Among the most encouraging is the substantial increase in the number of women attaining a Ph.D. in library science. At one time there were many more men in doctoral programs, but now the proportion of women has risen to 57 percent. Women constitute a similar percentage of assistant professors in li- brary schools, even though men still dominate the upper ranks. Since the number of men entering librarianship dropped to 17 percent in 1981, many women should have more opportunities for advancement in the future. ${ }^{35}$ Moreover, women are organized in such groups as ALA's Feminist Task Force and Women Library Workers. Workshops and preconferences have been held. Networking efforts with outside women's groups have also produced important results. These productive manifestations of the women's movement should produce substantial changes in female career patterns and remuneration in the university library.

\section{CONCLUSION}

Historically there have been three basic status and compensation problems in academic libraries: (1) the level of most salaries is lower than that of the teaching faculty; (2) compensation for administrative work is disproportionately higher than for service work; and (3) men in every category usually achieve higher status than women.

Regarding status, the most encouraging finding is that the administrative group has changed in seven years from 27.6 percent female to 45 percent female. This elite is such a small proportion of all female librarians, however, that the percentage of all females who are administrators rises less than 2 percent between 1976/77 and $1983 / 84$. Regarding salaries, the change in the sex differential has been minimal. The difference between the average salaries paid to all men and all women has dropped only 2.5 percent in seven years. Unless the pace accelerates, pay equity will not even be achieved by the year 2000 .

\section{REFERENCES}

1. Helen Remick, "Comparable Worth Definitions," in Pay Equity: Comparable Worth Action Guide, Topics in Personnel, no.2 (Chicago: American Library Assn., Office for Library Personnel Resources, 1982), Appendix A, p.1.

2. F. Y. Edgeworth, "Equal Pay to Men and Women for Equal Work," Economic Journal 32:431-57 (Dec. 1922).

3. Robert Mitchell and Shelley Phipps, "The Legal Basis for Equal Employment Opportunity and Affirmative Action," in Librarians' Affirmative Action Handbook, ed. John H. Harvey and Elizabeth 
M. Dickinson (Metuchen, N.J.: Scarecrow, 1983), p.66-70, 83-84; Jane Williamson, "The Struggle Against Sex Discrimination," Wilson Library Bulletin 57:304-7 (Dec. 1982).

4. Carole W. Wilson, Breaching the Next Barricade: Pay Equity for Women (Washington, D.C.: Union for Democratic Action Educational Fund, 1981).

5. Donald J. Treiman and Heidi I. Hartmann, eds., Women, Work, and Wages: Equal Pay for Jobs of Equal Value (Washington, D.C.: National Academy Pr., 1981), p.52.

6. E. Robert Livernash, ed., Comparable Worth: Issues and Alternatives (Washington, D.C.: Equal Employment Advisory Council, 1980), p.248-49.

7. Anita R. Schiller, "Women in Librarianship," in Advances in Librarianship, V.4 (New York: Academic, 1974), p. 125.

8. Ibid., p.126.

9. Ibid., p.125; Betty M. Vetter, Eleanor L. Babco, and Susan Jensen-Fisher, Professional Women and Minorities: a Manpower Data Resource Service, 4th ed. (Washington, D.C.: Scientific Manpower Commission, 1983), p.70.

10. Kathleen M. Heim, "The Demographic and Economic Status of Librarians in the 1970s, with Special Reference to Women," in Advances in Librarianship, V.12 (New York: Academic, 1982), p.2.

11. Anita R. Schiller, Characteristics of Professional Personnel in College and University Libraries, Research Series, no.16 (Springfield, Ill.: Illinois State Library, 1969).

12. Anita R. Schiller, "The Widening Sex Gap," Library Journal 94:1098-1100 (Mar. 15, 1969); "The Disadvantaged Majority: Women Employed in Libraries," American Libraries 1:345-49 (Apr. 1970); "Women in Librarianship, Status of," in ALA Yearbook 1976 (Chicago: American Library Assn., 1976), p.349-50.

13. Kathleen M. Heim and Leigh S. Estabrook, Career Profiles and Sex Discrimination in the Library Profession (Chicago:, American Library Assn., 1983); Kathleen Weibel and Kathleen M. Heim, The Role of Women in Librarianship, 1876-1976 (Phoenix, Ariz.: Oryx, 1979); Kathleen M. Heim, ed., The Status of Women in Librarianship (New York: Neal-Schuman, 1983); Kathleen M. Heim, "Women in Librarianship," in ALA Yearbook (Chicago: American Library Assn.), 1979, p.294-99; 1980, p.317-22; 1981, p.299-303.

14. David C. Weber and Tina Kass, "Comparable Rewards: The Case for Equal Compensation for Nonadministrative Expertise," Library Journal 103:824-27 (Apr. 15, 1978).

15. "Midwinter Notebook," American Libraries 10:57 (Feb. 1979).

16. William G. Jones, Salary Compensation Systems for Librarians: a Study of Ten Members of the Association of Research Libraries, Occasional Paper, no.5 (Washington, D.C.: Office of Management Studies, Assn. of Research Libraries, 1981).

17. Association of Research Libraries, Office of Management Studies, Classification Schemes, rev., SPEC Kit, no.7 (Washington, D.C.: Assn., of Research Libraries, 1978).

18. Frederick Duda, "Columbia's Two-Track System," College \& Research Libraries 41:295-304 July 1980).

19. Donald R. Cameron and Peggy Heim, The Economics of Librarianship in College and University Libraries, 1960-1970, a Sample Survey of Compensations (Washington, D.C.: Council on Library Resources, 1970); How Well Are They Paid? Compensation Structures of Professional Librarians in College and University Libraries, 1970-71, the Second Survey (Washington, D.C.: Council on Library Resources, 1972); Librarians in Higher Education, Their Compensation Structures for the Academic Year 1972-73, a Third Survey (Washington, D.C.: Council on Library Resources, 1974).

20. Cameron and Heim, Librarians in Higher Education, p.3.

21. Cameron and Heim, The Economics of Librarianship, p. 2.

22. Cameron and Heim, Librarians in Higher Education, p.6.

23. Richard J. Talbot and Ann von der Lippe, Salary Structures of Librarians in Higher Education for the Academic Year 1975-76 (Chicago: Assn. of College and Research Libraries, American Library Assn., 1976).

24. Ibid., p.6, 12.

25. Ibid., p.22.

26. Special Libraries Association, "A Study of the 1967 Annual Salaries of Members, Special Libraries 58:217-54 (Apr. 1967); "SLA Salary Survey 1970," Special Libraries 61:333-48 (July/Aug. 1970); "SLA Salary Survey 1973," Special Libraries 64:594-628 (Dec. 1973); "SLA Salary Survey 1976," Special Libraries 67:597-624 (Dec. 1976); SLA Salary Survey 1979," Special Libraries 70:559-89 (Dec. 1979); SLA Triennial Salary Suroey, 1982 (New York: Special Libraries Assn., 1983); "'SLA 1983 Salary Survey Update," Special Libraries 74:390-91 (Oct. 1983); "1984 Salary Survey Update," Special Libraries 75:338-40 (Oct. 1984).

27. "'SLA Salary Survey 1979," Special Libraries 70:561-62, 571, 580, 583 (Dec. 1979); "Errata, " Special 
Libraries 71:182 (Mar. 1980); "Errata," Special Libraries 71:542 (Dec. 1980).

28. Association of Research Libraries, ARL Annual Salary Survey, 1976-77, 1977-78, 1978-79, 1979-80, 1981, 1982, 1983, 1984, (Washington, D.C.: Assn. of Research Libraries, 1977-85).

29. "Women and Education," WEAL Washington Report 13, no.3:3 (June/July 1984).

30. Cameron and Heim, Librarians in Higher Education, p.11-13.

31. Association of Research Libraries, ARL Annual Salary Survey, 1983 (Washington, D.C., 1984), table 15: Number and Average Salaries of ARL University Librarians by Years of Experience, Fiscal Year 1984, p. 28.

32. Barbara B. Moran, "Career Patterns of Academic Library Administrators," College \& Research Libraries 44:334-44 (Sept. 1983); Betty Jo Irvine, "ARL Academic Library Leaders of the 1980s: Men and Women of the Executive Suite," in Options for the 80s, ed. Michael D. Kathman and Virgil F. Massman, Proceedings of the Second National Conference of the Association of College and Research Libraries, Foundations of Library and Information Science, V.17 (Greenwich, Conn.: JAI Pr., 1982), Part B, p.423.

33. "'California Librarians Tell Employers: 'Equal Pay for Equal Work!' " Wilson Library Bulletin 51:393 (Jan. 1977); Sue Galloway, "Discrimination and Affirmative Action: Concerns for Women Librarians and Library Workers," in Librarians' Affirmative Action Handbook, ed. John H. Harvey and Elizabeth M. Dickinson (Metuchen, N.J.: Scarecrow, 1983), p.155-58, 161; Helen Josephine, "All Things Being Equal: Pay Equity for Library Workers," Wilson Library Bulletin 57:301 (Dec. 1982); Helen Josephine, "Up Your Wages," WLW Journal 8:14-15 (Apr./June 1983).

34. U.S. Congress, House, Committee on Post Office and Civil Service, Pay Equity: Equal Pay for Work of Comparable Value, Joint Hearings Before the Subcommittees on Human Resources, Civil Service, Compensation and Employees Benefits, 97th Cong., 2d sess., 1982, Part 1, p.476, 487-89, 502-06, 575-96; Edward G. Holley, "The Merwine Case and the MLS: Where Was ALA?" American Libraries 15:327-30 (May 1984); Robert Wedgeworth "ALA and the Merwine Case: A Word as to the WHYS," American Libraries 15:561-62 (Sept. 1984); Pauline Wilson, "ALA, the MLS, and Professional Employment: An Observer's Field Guide to the Issues," American Libraries 15:563-66 (Sept. 1984); "Merwine Asks Supreme Court to Consider ALA/MLS Case," American Libraries 16:460 (July/Aug. 1985): "U.S. Supreme Court Decision Boosts ALA-MLS Requirement," American Libraries 16:757-58 (Dec. 1985).

35. Kathleen Heim, "Fighting for Social Change: Library Women Enter the Eighties," Wilson Library Bulletin 57:309 (Dec. 1982). 